\title{
IN THE SHADOW OF EMPIRE: REFLECTING ON THE POLITICAL STRATEGIC POSITION OF SMALL STATES IN EUROPE AND THE CARIBBEAN BASIN DURING THE COLD WAR
}

\author{
Mitchell Belfer ${ }^{1}$
}

\section{Introduction}

Any evaluation of $20^{\text {th }}$ century international political and socio-economic engagements inevitably draws heavily on the literature depicting the relations between and within the Cold War blocs. Such cognitive benchmarking has become so extensive that even the earth-shattering World Wars, which preceded US-Soviet brinkmanship, have been sewn together to the Cold War so as to produce a meta-narrative as a means of understanding the dynamics of international relations themselves. For instance, WWI has not merely entered the history books for what it produced; it has also come to be seen as producing the right conditions for Russia's communist revolution and the US's rise to inherit the position of Western leadership_two necessary prequels to the half century of Cold War. But not before these two ideologically opposed blocs join forces to rid the world of fascism and the German pivot in European affairs. WWII has come to represent three chapters in the story of civilisation: the story of genocide (re: Nazi Germany's quest to exterminate world Jewry), the

${ }^{1}$ Head of the International Relations and European Studies Department and Editor-in-Chief of the Central European Journal of International and Security Studies at Metropolitan University Prague. Email: belfer@mup.cz. 
story of non-nationalistic secular ideological struggles and the story of power beyond the pale of power (re: the nuclearisation of power). In other words, WWII has also, largely, been included as a necessary chapter to the Cold War. And certainly it was. Without WWII it is difficult to imagine how, or if, the USSR would have driven west and occupied Central Europe, whether the West European states would not have deployed East, if the US would have deepened its engagements to Europe or any number of dynamics would have unfolded. It is clear that the Cold $\mathrm{W}$ ar is a defining period of international relations history.

Yet, such grandstanding, by its nature, implies the imbalance of global power to the point that only two state-blocs are said to have dominated international political life for the better part of a century. While this may be empirically verifiable in terms of deployments, engagements and projections there are fatal flaws with such generalisations; they tend to overstate the roles of the superpowers and under-appreciate the roles of smaller states and the alliances and competitions that defined their global position and foreign policy orientations. These too were - and are - important and deserve both recognition and exploration.

This work takes a stab at redressing the instinctive neglect of the small states that affected the Cold War system of transatlantic and transpacific competition and has bled over to more recent times. While delving into the dynamics of small states in a world system dominated by superpowers requires exhaustive investigations, this work provides only a modest baby-step. Its intention is to define, conceptually, small states and demonstrate how these have come to occupy the proverbial "shatterbelts" that exist in the "friction zones;" the overlapping spaces of super- and great powers' spheres of influence. Since the Cold War was (roughly) divided into two main blocs, and given that the flexibility of small states to determine their own foreign policy direction was severely restrained by their bloc-leader, explorations of small state relations during the Cold War are limited to the intra-bloc level. For the purposes of this work, examples are drawn primarily from the superpowers' immediate geopolitical spheres of influence - the US and Central and South American states and the USSR and the Warsaw Pact countries - since this work is concerned with how the small states, in the shadow of empire, determined their relations. These regions are also important since the USSR sought to check US power in the Americas through the sponsorship of communist military, 


\section{Mitchell Belfer}

paramilitary and political activities while the US reinforced anti-communist governments in Western and Southern Europe and spent considerable energies galvanising NATO. In short, the Caribbean was to the USSR what Western (and Southern) Europe was to the US; a pressure point on the geostrategic body of its adversary. Additionally, the geographical, cultural, socio-political and economic differences between the US's and Soviet's spheres render comparison both interesting and stimulating. This work is organised accordingly.

\section{Theorising on Small States}

The importance of small states in the preservation of a regional or even the international balance of power should not be understated. Just as Belgian neutrality helped preserve the pre-WWI balance of European power, so Georgia's more recent attempts to enter Western security organisations prodded Russian aggression. Large and superpowers go to great lengths to anchor small states into their security architecture and jealously defend the status quo whether the people of such small states agree or not. Democracy is a luxury for states obsessed with their perceived geopolitical survival. With this in mind, it is necessary to define small states and evaluate their specific behaviours vis-àvis the world's great and superpowers. Since this work is devoted to understanding the political nuances during the Cold War years, attention is paid to the period 1945-1991. Additionally, this section is not exclusively focused on relations between the members of the Soviet's two pincers - the Warsaw Pact states and the "stragglers of the Caribbean" - but seeks to provide a wider understanding of small states.

\subsection{What are Small States?}

A distinct body of international relations literature focuses on the nature, behaviour and policy orientations of small states and small powers. ${ }^{2}$ This collection of texts provides a solid arch between historic (re: the Republic of Venice) and more contemporary examples of small states (re: The Grand Duchy

${ }^{2}$ This theoretical section first appeared in: Mitchell Belfer (2014), Small State, Dangerous Region: A Strategic Assessment of Bahrain, Peter Lang Publishing, Frankfurt, Germany. 
of Luxembourg). However, such treatments tend to be generalisations in that many of their assumptions are time-specific and seldom appreciate changes to the fabric of international relations. In other words, many of the scholars who examine small states tend to act as historians, rather than international relations scholars, and freeze-frame the small states of their investigations. The idea that there are small and medium, large, great and superpowers operating in the international arena is hardly novel; international relations scholarship has been concerned with such distinctions from its inception. Therefore, to determine precisely what a small state is, it is essential to take a theoretical back-step, to the "last year of the Napoleonic Wars. Previously [...] "the assumption had been that all sovereign and independent states were in theory equal, whatever might be their responsibilities or physical strength."'3

From this initial point, the assumption was that all states had been considered equal and the principle of non-intervention into the domestic affairs of other states was set as an iron rule. However, such iron rules are typically bent by the raw muscle of great powers, which, in their determination to extend their power-bases and projection capacities often got involved in others' affairs; small and large alike.

Indeed, Rothstein recalls that the

[...] presumed equality of all states did not, of course, prevent the Great Powers from treating weaker states instrumentally. Small Powers threatened by neighbouring Great Powers, or intent on security benefits for themselves in the course of Great Power conflicts, were forced to play a perilous game: moving quickly from the lighter to the heavier side of the balance as soon as an apparent victor in any contest could be discerned. ${ }^{4}$

Such sentiments point to pragmatic leadership as the pillar for nationalstate longevity since - if small states were treated instrumentally and were forced to quickly shift their alliances - only prudent leaders are able to recognise power shifts and rapidly realign to ensure survival. Yet, small states do not operate from within a political vacuum and they are not blessed with

\footnotetext{
${ }^{3}$ Harold Nicolson (1961), The Congress of Vienna: A Study in Allied Unity, 1812-1822, NY: The Viking Press, p. 137, quoted in Robert L. Rothstein (1968), Alliances and Small Powers, Columbia UP, p. 11.

${ }^{4}$ Robert L. Rothstein (1968), Alliances and Small Powers, Columbia UP, p. 11.
} 


\section{Mitchell Belfer}

having only to deal with regional balancing in an effort to defend their interests and ensure their survival. Often, small states are themselves the issue which inspires great power competition and, at times, conflict. Cuba's chapter in communist revolution is a reminder of the intensity great powers may be willing to go in order to project themselves and absorb small states into their spheres of influence; the international community had never before - or since - been closer to nuclear Armageddon as the US quarantined the Island and actively deterred further Soviet expansion. Castro understood how antagonistic his regime was to the US, and made his alignment choices accordingly. However, he could not anticipate the lengths the US was willing to go in order to preserve the regional balance of power-and terror. Castro's pragmatism was less than optimal and Cuba has suffered economically as a result. But yet, it has survived. The same could be said of a later attempt to set up a (claimed) radical communist regime in Grenada following the 1983 assassination of Prime Minister Maurice Bishop. The US's Operation Urgent Fury amounted to the rendering of an independent Grenadine state to the humiliating position of pseudo-puppet of the US. When small states act imprudently and without regard for their role in preserving a regional balance of power, they risk their national sovereignty and survival.

So, small states must not only be concerned with regional balancing, they must also attempt to keep a "low profile" since those small states that "came to the attention of the Great Powers [...] were only noticed when they became an object of desire for a Great Power, or when they intruded too noticeably in the diplomatic game."5

For Rothstein, small states are understood to be defined according to three important benchmarks. Firstly, that they are treated instrumentally, that there is an invisible hand which determines their freedom of action and limits the extent of their independence in terms of developing an foreign policy entirely rooted in national interests defined according to the demands of the population and political classes. Secondly, that small states are forced into a perilous game of constant balancing, expending tremendous political and economic energies (and resources) to ensure that they are on the "winning" side of a balance and do not get caught-up in regional and international

${ }^{5}$ Ibid, p. 12. 
competitions beyond their capabilities. And, finally, that small states are specifically restricted in foreign policy making in that larger powers' foreign policies act as the basis for small states' decision-making.

Even a cursory glance at many of the Latin American, Caribbean and Central/Eastern European states - in the shadow of the US and Soviet empires - confirms the validity of Rothstein's observations. The Soviets were less concerned with the Cuban revolution and social justice in that country than they were of off-setting US power in the Northern Caribbean region, just like the US was hardly concerned with the fallout of the coup d'état against Allende and the emergence of the Pinochet regime in Chile. ${ }^{6}$ Such instrumental treatments of allies was hardly confined to Latin America; Central and Eastern European states faced similar conditions as the 1956 Russo-Hungarian conflict and the 1968 Warsaw Pact invasion of Czechoslovakia attest. But whereas Rothstein suggested that "an invisible hand" determined small states' freedom to formulate an independent foreign policy, the Cold War superpowers were not subtle; the hand was visible and clenched.

In terms of being "forced into a perilous game of constant balancing [...] to ensure that they are on the 'winning' side of a balance and do not get caught-up in regional and international competitions beyond their capabilities," the level of instrumentalism precluded alliance fluidity among the small states during the Cold War. Sure, both Albania and Romania abandoned the Warsaw Pact, and it is true that France withdrew from military cooperation in NATO, however in no case did such alliance defections threaten bloc political security and, besides, these episodes served more as exceptions than the rule. For the most part, the Cold War was a grand balancing act and the small states were largely locked into it as a result of their instrumental treatment by the superpowers. There were few avenues of recourse. Albania had to tie itself to an invigorating China, Romania had to flirt with the US, France and Italy while France had to remain committed to the US on a bilateral level. In each case of Cold War bloc adjustments, balances were reaffirmed rather than disregarded. ${ }^{7}$

${ }^{6}$ See: Peter Kornbluh (2003), The Pinochet File, The New Press, New York: USA.

${ }^{7}$ See: Raymond L. Garthoff (1995), The Cold War International History Project Bulletin, Issue 5, p. 111. 


\section{Mitchell Belfer}

Finally, that small states are specifically restricted in foreign policy making in that larger powers' foreign policies, act as the basis for small states' decision-making was a very important observation. When the USSR sought inroads into Latin America, it enlisted its Czechoslovak ally since the latter retained (relatively) good relations in the region. Czechoslovakia's acceptance of playing the role of trailblazer had less to do with instinctive Czechoslovak policy preferences and more to do with the fact that foreign policy decisions were increasingly made in, and by, Moscow. ${ }^{8}$

In the heat of the Cold War, Rothstein remarked that "for Small Powers [...] the solution to any 'security-dilemma' must come from an outside source." In the breakdown of US hegemony this is again a key feature of being a small state, however at this time in history being able to solve a security dilemma is much more difficult owing to the nature of regional competitions, especially in dangerous regions. The Caribbean Basin, Latin America and Central/Eastern Europe were - throughout the $20^{\text {th }}$ century - terribly dangerous. Whether referring to the Maoist Shining Path insurgency in Peru, the incessant interstate conflicts in Central America, notably the famous Postage Stamp War of 1937 between Nicaragua and Honduras, the 1969 Football War between El Salvador and Honduras and the simmering (often erupting) tensions between Costa Rica and Nicaragua over the San Juan River, to name a few, there is a disproportionate level of political violence in and around the southern 3/4ths of the Americas. This is mostly due to the high proportion of small states and their security requirements only able to be fulfilled through the enlisting of large regional or international powers. Hence, while the solution to their security dilemmas must come from an outside source, such exogenous actors may be, at least partially, responsible for the initiation of the security dilemmas in the first place since the exogenous state treats the small state instrumentally; in pursuit of its own interests. Small state conflict may, very well, be the residue of great powers' pursuits of their interests.

\footnotetext{
${ }^{8}$ See: Matyas Pelant (2013), 'Czechoslovakia and Brazil, 1945-1989: Diplomats, Spies and Guerrilheiros,' Central European Journal of International and Security Studies, 7:3, pp. 96-117. See also: Josef Opatrny (2013), 'Czechoslovak-Latin American Relations, 1945-1989: The Broader Context,' Central European Journal of International and Security Studies, 7:3, pp. 12-37.

${ }^{9}$ Rothstein (1968), p. 24.
} 
Indeed, similar to the pre-WWI/WWII periods,

Small Powers must, therefore, rely on essentially ambiguous external aid for the accomplishment of the basic goal of all states: survival. If they have learned anything from history, it is that external support usually arrives late, and that it is given only in expectation of future benefits. ${ }^{10}$

Additionally, there is a "narrow margin of safety which a Small Power possesses. With a small territory (normally), with few resources, and with uncertain friends, it has very little time in which to correct mistakes. Fearing to take risks, caution is enjoined."11 The Hungarian revolution serves as a case in point. ${ }^{12}$ While the US and its Western European allies certainly encouraged the Hungarians to rebel against the USSR for the purpose of fracturing the communist presence in Central Europe, there would be no support when Hungary needed it most. ${ }^{13}$ Instead, Hungary had to absorb all the risk and paid for its miscalculations in blood and harsh political and economic restrictions following the Soviet invasion. And, to add insult to injury, it seems that the manner in which the US sought to empower Hungary's more moderate communists, may have directly contributed to the Soviet decision to invade the country and depose Nagy. ${ }^{14}$ Meanwhile, by the time the US had mobilised its allies to even agree on lending support to the Hungarians, the war had already been concluded. The West, it seems, was ready to fight the USSR to the last Hungarian.

Small states are not only vulnerable owing to their dependence on unreliable and selfish allies, they are additionally - owing to the size of their territory - made vulnerable based on their geopolitical position and, importantly, the shortened timeframe they are forced to operate from. Political life is simply accelerated because patience is a luxury small states can ill-afford. Indeed, "few Small Powers enjoy the luxury of possessing enough strength to

\footnotetext{
${ }^{10}$ Ibid, p. 24.

${ }^{11}$ Ibid, p. 25.

12 See: Johanna C. Granville (2004), The First Domino: International Decision Making During the Hungarian Crisis of 1956, Texas A\&M UP.

13 See: Ibid.

${ }^{14}$ Ibid, pp. 200-201.
} 


\section{Mitchell Belfer}

handle all the problems on their political horizons; at best, they may be able to confront and survive the most serious problems, provided they perceive them accurately."15

So, an additional aspect of small states, recognised as the central pillar for their survival rests on leadership and decision-making. It is as though all small states are permanently on war-footing, rapidly altering policy as new information streams in. Foreign and defence ministries, the office of Prime Minister and, basically, the entire spectrum of executive and legislative personnel, are forced to work constantly, and prudently, if their state is to survive. This may, perhaps, offer a partial explanation as to the forms of government adopted in both Central/Eastern Europe and Latin America during the Cold War; strong leadership, cults of personality and raw populism. ${ }^{16}$ Often the internal dimensions of policy-making lay beyond the scope of adequate investigation, however, in small states there is a prevailing national feeling of fear that a policy choice is inadequate or that certain regional tides are too strong to resist and "the psychology of fear leads Small Powers in conflicting directions,"17 which are very difficult to reconcile.

\subsection{What Makes a Small State Small? Two Variables.}

For all the previous discussion about the intrinsic vulnerabilities, which define small states, it is also important to clearly indicate particular aspects of a state which render it small and hence prone to the vulnerabilities highlighted above. For the purposes of this work, there are two main approaches to understanding what makes a small state small, an absolute and a relative, both of which are reflected in the interaction of two variables.

\footnotetext{
${ }^{15}$ Rothstein (1968), p. 25.

${ }^{16}$ For a reading into economic populism in Latin America see: Sebastian Edwards (2010), Left Behind: Latin America and the False Promise of Populism, University of Chicago Press. While this work is geared towards explaining the manner in which policy orientations and ideologies have largely plagued Latin American economic growth, it hints at the forms of nepotism and sectoral empowerment that is often a reflection of both paranoid and cultish leaders. For a reading into the cult of personality and leadership in communist Central and Eastern Europe during the Cold War see: Ben Fowkes (1999), The Post-Communist Era: Change and Continuity in Eastern Europe, Palgrave Macmillan, New York: USA.

${ }^{17}$ Rothstein (1968), p. 28.
} 
These are:

1. Population Size: the total number of residents (citizens and non-citizens alike) of a given state;

2. National Territorial Area: the geo-strategic depth of the state and the resources available to it.

These are borrowed (though refined) from East's four variable depiction of the "conventional model" of a small state where he suggests that

This conventional model generally assumes that small states are characterised by one or more of the following: (1) small land area, (2) small total population, (3) small total GNP (or other measure of total productive capacity, and (4) a low level of military capabilities. ${ }^{18}$

The decision to omit GNP and the level of military capabilities was made on the basis that GNP refers to the size of a country's economy and not its geopolitical dynamics. At the same time, international relations and security are much more nuanced and the strict criteria of maintaining a low level of military capabilities is not an indication of national size, or power (for that matter). Instead, while not considered a variable, this work recognises the variance of national demands and the capabilities to satisfy them as indicative of a small state since it seems that small states feel national (and sectorial and sub-national) demands much more acutely than larger entities. Owing to the fact that a small state is territorially small and contains a small population, it follows that there will be less demands and more opportunity to satisfy such demands. Or, alternatively, there may be more demands and less opportunity to satisfy them, implying that small states are forced to behave differently than larger entities owing to the inherent internal tensions that are derived from the variance between demands and national capabilities. However, since such situations arise as a symptom of being small and not a cause, demands vs. capabilities are understood as symptomatic.

\footnotetext{
${ }^{18}$ Maurice A. East (1973), 'Size and Foreign Policy Behaviour: A Test of Two Models,' World Politics, $25: 4$, p. 557.
} 


\section{Mitchell Belfer}

\section{Variable 1: Population Size}

Population size continues to matter in terms of fielding adequate numbers of citizens for political, military, social, diplomatic and economic activities. While using population as an indication of "small" or not small has been the centre of many international relations debates, it is a key determinate deployed throughout this work. ${ }^{19}$ Sawyer notes that

Of all national characteristics, size is probably the most obvious-but this makes it no less important. And although population is the most prominent representative of size, such variables as a nation's energy resources, arable land, and GNP also load highly on this factor. ${ }^{20}$

This work also recognises that other factors may be considered for the overall understanding of what makes a state small or large (or other sizes for that matter), though maintains that population size is the most relevant since only through the fielding of individuals into a states' political structures, its armed forces and its economic agents and bodies can national mobilisation occur. Given that small states have a smaller pool of individuals to fill such positions and roles, it stands to reason that small states are characterised by small pools of individuals and hence size does matter; if a state has less politically capable persons to draw on, less soldiers to conscript or enlist, and less economic actors then the entire national apparatus will be affected even if the state in question is wealthy and controls significant natural resources.

It is also useful to note that population size does not positively reflect power - small states may be relatively powerful or weak - it depends on a wide assortment of interacting variables. In this, despite the fact that "merely possessing a larger army, more advanced weapons, or a modern economy does not guarantee the ability to achieve desired ends - the relationship between tangible power and the achievement of national goals has become more and more indirect and obscure." 21 So, small states may retain power and large states

\footnotetext{
${ }^{19}$ For an overview of the population size debate see: Maass (2009), pp. 70-74.

${ }^{20}$ Jack Sawyer (1967), 'Dimensions of Nations: Size, Wealth and Politics,' American Journal of Sociology, $73: 2$, p. 152 .

${ }^{21}$ Rothstein (1968), pp. 19-20.
} 
may be weak. However, the size of the national entity does impact on the way the state behaves since small states tend to rely on alliances and are more acutely aware of their vulnerabilities than larger states are. Hence, understanding the role that population size plays in national political cultures and behaviours is an important task. Unfortunately, discussion in this section departs from such theorising to return to the task at hand; determining the criteria required to define a state as being small (or otherwise).

The Absolute Approach-looks at the total number of a state's inhabitants citizens and residents - and if the population size is 1.5 million or less it is considered a small state. This number is not arbitrarily ascribed, it has been selected since the vast majority of recognised national state enterprises consist of populations which number more than 1.5 million and thus states with (or less than) such a population base are in the clear minority..$^{22}$ Additionally, in states with (or less than) such a population base it may be assumed that less than one million are eligible members of the state's economic, political, social and military life. So, a population of one and a half million, after deducting the number of aged, young and incapacitated, results in a population of roughly one million contributing persons. Although such states are comparatively rare, there are still numerous examples of them, though for the case at hand, these tend to be found in, or proximate to the Caribbean region - both island states and along the littoral - not among the Central and Eastern European states during the Cold War. ${ }^{23}$ Consider for example: Anguilla (UK, 12,000), Antigua and Barbuda (73,000), Aruba (Netherlands, 100,000), The Bahamas $(310,000)$, Barbados (270,000), Belize (256,000), Bermuda (UK, 82,000), Cayman Islands (UK, 40,000), Dominica (79,000), French Guiana (France, 178,000), Grenada $(80,000)$, Guadeloupe (France, 440,000), Guyana (765,000), Martinique (France, 393,000), Montserrat (UK, 4000), Netherlands Antilles (Netherlands, 221,000), St. Kitts and Nevis $(42,000)$, St. Lucia $(149,000)$, St. Vincent and the

22 Of the 193 current members of the United Nations General Assembly, 150 have populations that exceed 1.5 million people implying that less than a quarter of all recognised states retain populations smaller than 1.5 million.

${ }^{23}$ It should be remembered that as some of the larger states fragmented, notably Yugoslavia, the succeeding states may have had populations of less than 1 million. For instance, Montenegro's population is just over 600 thousand people. 


\section{Mitchell Belfer}

Grenadines (120,000), Surinam (435,000), Trinidad and Tobago (1.3 million), Turks and Caicos Islands (21,000), Virgin Islands (UK, 21,000) and the Virgin Islands (US, 111,000). These account for roughly half of the international community's absolutely small states. ${ }^{24}$

So, for a state to qualify as absolutely small it needs to have a population of 1.5 million or less and an active, participating population of between 8 hundred thousand and 1.2 million people. In the Caribbean basin region, the vast majority of the states and territories are absolutely small. Hence, the depiction of small state behaviour (above) may be applicable since few of these states retain adequate means of self-defence and hence are treated instrumentally by the dominant regional power, the US. There were, to be sure, times where some of the more enterprising regional powers such as Cuba and Venezuela have attempted to disrupt the regional balance of power - a.k.a. US regional hegemony - but such attempts were only half-witted and haphazard.

The Relative Approach-is, in contrast, based on a 10 per cent rule, where a state is considered small relative to any one of its territorial neighbours or, in the case of island states, a state sharing the immediate littoral of the body of water surrounding it. This approach offers important insights regarding small states since it is based on relative power assessments derived from a states' demographics which - while not always a fair assessment - allows researchers to hypothesise on capabilities since states with larger populations should (in most cases) be able to enlist greater numbers of its citizens for political assignments, active armed services and economic life. Certainly, there are problems with such an approach since it does not automatically suggest power imbalances; many additional factors must be considered. For instance, large states may be more fractured, less cohesive and have fewer resources available to the state rendering it relatively weaker than a smaller adversary. While such lines of thinking is surely valuable, it is not relevant for the current discussion which narrowly seeks to illustrate what a small state is, not its power capabilities. So, with this approach in mind, when a state retains a population 10 per cent the size of a neighbour it is relatively small. With few exceptions, the states that bordered

${ }^{24}$ Atlas of the World, Reference Edition, The Times of London, London: UK, (2011), pp. 18-37. 
on the US (237 million in 1985) and USSR (277 million in 1985) were often less than 10 per cent their size. In the Caribbean and Latin America only Mexico, Argentina and Brazil retained (in 1985) populations that exceeded the 10 per cent rule. In contrast, during the same period, only Poland was more than 10 per cent of the USSR's total population.

\section{Variable 2: National Territorial Area}

As a variable, the national territorial area indicates two key ingredients of capabilities that may render a state small or not: levels of geo-strategic depth and the presence of a sustainable resource base (including resource accessibility, conversion and mobilisation options ${ }^{25}$ ). Unlike the manner in which population was treated above - in terms of presenting both the absolute and relative approaches separately - this subsection blends the absolute and relative approaches into the main arguments.

Geo-Strategic Depth-determining the geo-strategic depth of a state is a daunting task since it is an ambiguous variable with few mechanisms of measurement available to social scientists. ${ }^{26}$ Often, the phrase geo-strategic depth is deployed in a reified manner and no clear definitions offered. This work offers an imperfect definition, though hopes that this endeavour is further developed in other works. For the purposes at hand, geo-strategic depth is considered the amount of territory a state may cede to an invading military force before having to cede ultimate sovereignty. In other words, the percentage of territory that would need to remain under the control of government " $A$ " for that government to legitimately claim to extend sovereign control over country "A."

25 These sub-variables are borrowed from Jeffery Hart (1976), 'Three Approaches to the Measurement of Power in International Relations,' International Organisation, 30:2, pp. 289-305.

26 Most scholars tend to view strategic depth as an abstraction rather than a reality of a state's geopolitical thinking. See, for instance, Faruk Yalvac (2012), 'Strategic Depth or Hegemonic Depth? A Critical Realist Analysis of Turkey's Position in the World System,' International Relations, 26:2, pp. 165-180. While Yalvac certainly contributes to the discipline of international relations through this article, it does not offer many clues as to how geo-strategic depth may be universalised as a concept and deployed in the political orientations of states. At least Yalvac attempts to understand geostrategic depth; most others simply assume broad knowledge of the theme and omit defining it. 


\section{Mitchell Belfer}

Consider a counterfactual situation to illustrate this point. Imagine that the Nicaraguan civil war occurred at a time of US determination to advance the cause of human rights in Central America and hence brought the superpower in to allay the dangers to the civilian population. ${ }^{27}$ In the event that the US were to construct a 10 kilometre "humanitarian corridor" within Nicaraguan territory - adjacent to the Costa Rican border - for the sake of offering civilians a safe haven and thereby forcing the Sandinistas 10 kilometres back from their sovereign boundaries. Nicaragua would not cease being an independent and legitimate state as a result of such an intervention. Nicaragua's geo-strategic depth is greater than 10 kilometres. Alternatively, if the US (in this hypothetical) were to extend its corridor 250 kilometres to include the major part of Nicaragua's population and its industrial capabilities Nicaragua would cease being Nicaragua in its current form and be forced to adjust to being a smaller entity, say centred around Managua, or seek to regain its lost territories through guerrilla conflict. In either case, the country and its leadership would be deemed illegitimate leaders of Nicaragua, though may still be regarded as the legitimate leaders of Nicaraguans.

In this hypothetical example, Nicaragua's strategic depth vis-à-vis the US is something around 250 kilometres. Yet even this is not a rule. If, for instance, Honduras would have militarily intervened in our Nicaragua story to end the inevitable migration of fleeing civilians - it would not require a 250 kilometre occupation zone in order to deconstruct Nicaragua, it would only need to occupy the capital, Managua. If Honduras would successfully do so, the Nicaraguan authorities would either be deposed (killed, arrested, exiled) or forced into the hinterland to carry on the conflict using asymmetric means. In any case, this would imply that Nicaragua's leaders could not effectively develop or implement policies for the country and hence the state would no longer exist as a unit. From this example it is clear that there are two main determinates of geo-strategic depth. Firstly, a kilometre-based determinate whereby a state's geo-strategic depth is measured according to how much of its

27 Please note that this is a counterfactual argument. Historically, the US's support to President Somoza's dictatorial regime is often cited as a main cause of the 1978/1979-1989 civil war since it empowered one bloc against the country's civil society, rural classes and the intelligentsia. The civil war only ended with the signing of the Tela Accord of which the US's role was only marginal. 
national territory it must retain in order to remain the same state. Or, how much ground can it lose before it ceases being a state.

The second determinate is based around the control of the state in question's capital city since doing so has tremendous symbolic and practical meaning; it indicates that a government has lost direct control of the state's decision-making apparatuses and institutions and that the state has ceased to exist in its previous form. Consider that the USSR did not have to occupy all of Hungary to force the latter to surrender in 1956; it needed only reach Budapest and exile, kill, imprison or co-opt members of the executive, legislative and judicial branches of government. While this may serve as an example of the capital city of a state as a key determinate to its geo-strategic depth, it should also be noted that threats made against a capital city can act as an effective tool in the exercise of power.

The above theorising intended to play with some of the ideas attached to geo-strategic depth. However, these have been limited to large(r) state entities and have, so far, excluded small states. While the general theory being applied here is valid for small states, the point is that retaining a small territorial surface implies retaining a more limited geo-strategic depth. Nicaragua's loss of 10 kilometres would not automatically end its sovereignty. However, if the US would invade 10 kilometres of Grenada (as it did), the latter would cease to exist and be forced to accept US domination (which it also did). For the purposes of this work then, small states naturally have a smaller geostrategic depth than larger entities, owing to the territorial surface of the state. Hence, small states are intrinsically vulnerable since foreign occupation is made easier by small territorial surfaces and the lack of adequate geo-strategic depth.

For instance, Cuba is a relatively small island state and Czechoslovakia (was) a small territorial state and Quester's remark that chief among the vulnerabilities of such states is that "there is no hinterland for the inhabitant of the island to retreat to, there is no second line of defence, no backup position from which to repulse such foreign aggression"28 is relevant. Islands are even

\footnotetext{
${ }^{28}$ George H. Quester (1983), 'Trouble in the Islands: Defending the Micro-States,' International Security, $8: 2$, p. 161 .
} 


\section{Mitchell Belfer}

more vulnerable than continental small states since there are no porous borders to sneak across for asylum, no safety nets and no safe havens.

Sustainable Resource Base-examines the ability a state has to practise autarky in terms of providing essential resources for the sustainability of its population based on extraction from the national territorial surface. In the contemporary international environment, complex as it is, the necessary ingredients for socio-political survival remain relatively constant. There are five. Firstly, arable land is required for hygienic living spaces and to meet dietary needs such as adequate agriculture and raising livestock for consumption. Secondly, but no less important, people require potable water; the fresh, purified water for consumption, food preparation, enabling agriculture and for ensuring sanitary conditions (cleaning of living spaces and people). Water is also an essential ingredient in modern medicines and industrial activities. Thirdly, access to energy sources adds an important dimension to the list of required resources for any political community. Energy resources may be more archaic, such as lumber. They may be oil and gas or even more sophisticated sources such as biomass. Communities need energy to light and warm their homes, prepare foods, for sterilisation of daily and medical utensils and, in more advanced societies, to power their cities, run the transportation links and provide the luxuries attached to modern living. Fourthly, human resources are required to fulfil the basic operation of a community (no matter the size). People need to be able to field key positions related to public services (police, armed forces, government, farmers, etc.) and sectors related to resource extraction, conversion and mobilisation. Finally, all political communities require adequate living spaces, places where individuals and families may habitat and public spaces where social interactions and exchanges may occur. These are the basic resources required of any community. As societies advance, so do required and desired resources; educational, industrial, commercial and social. In terms of retaining a sustainable resource base, it is clear that small states are (nearly always) at a disadvantage owing to their territorial surface size. While there is no way to determine what makes a state small according to a strict square kilometre assessment, it is possible to hypothesise according to the 
blend of relative and absolute understandings of territorial size comparing inhabitants per kilometre to territorial area size.

\subsection{Territorial Size as a Determinant of Small States}

Population size was deployed as a variable that can be operationalised in order to, partially, determine whether or not a state is small. This section seeks to do the same with the use of territorial size. While the variable itself was explained in some depth above, this subsection presents the absolute and relative approaches required for its operationalisation. Both approaches are more concerned with the actual and potential strategic depth of states rather than a state's sustainable resource base. This selection is based on the premise that even large states may not have adequate resources for national sustainability and therefore engage in international trade to that end. At the same time, small states may, very well, retain sustainable resources for their population's needs. So, while the amount of resources is important, particularly in competitive environments, it is not utilised or further developed in the subsequent section since it may only complicate being able to comprehensively identify a state as being small.

By way of illustration, consider the example of Peru with a population of some 28 million, stretched over more than 700 thousand square kilometres. Despite its size, only a fragment of its territory is arable owing to the Andes Mountains and the protected rainforests. Hence, Peru requires international trade relationships in order to meet the basic needs of its population. ${ }^{29}$ At the same time, Costa Rica's population is situated at approximately 4.5 million on a minute territorial surface, of which roughly 35 per cent is arable, implying that Costa Rica has sufficient agricultural capabilities. ${ }^{30}$ This disparity in sustainable resources does not indicate either the absolute or the relative size of Peru or Costa Rica. Instead, it only exposes one dynamic. Therefore, resource sustainability is omitted from further discussion here though accepts the assumption that small states tend to have more acute difficulties in meeting the resource demands of their population. This is a point of reflection rather than a

\footnotetext{
29 This information is based on the CIA Factbook 2013 (hereafter CIA Factbook) available at: <www.cia.gov/library/publications/the-world-factbook/geos/eg.html> (accessed 07 September 2013). ${ }^{30}$ CIA Factbook.
} 


\section{Mitchell Belfer}

rule. The following points then, indicate the absolute and relative territorial size of a state for the purpose of indicating its strategic depth.

Absolutely - small implies that the state in question contains territories smaller than 5000 square kilometres. This territorial determinant was selected due to a maximum 222.5 kilometre depth of the state in question. In other words, being able to enter a state from its frontiers and reach the geographic centre within 222.5 kilometres implies minute strategic depth and therefore indicates that the state is absolutely small. Topographical features may certainly facilitate or impair an invading military and certainly if a state has 5001 square kilometres it is in no better position, however there seems to be a major leap statistically from states that have less than 5000 square kilometres to those that retain 7000 and more. In other words, there are few states with 5000-7000 kilometres and therefore it seemed natural to place the threshold at 5000 square kilometres. $^{31}$ In terms of topography, it should be noted that technological innovations over the past fifty years, particularly in aircraft and missile technologies, implies that territorial obstacles are more easily overcome. In this way, 5000 square kilometres offers next to no protection from air operations since such states can be over-flown in less than 20 minute. Such states are, therefore, absolutely vulnerable. In Central and Eastern Europe all countries have landmasses that exceed the 5000 square kilometre rule. In the Caribbean and Latin America, on the other hand, most of the island states retain significantly less territorial surfaces. For instance, Dominica (751 square km), Saint Lucia (616 square km), Antigua and Barbuda (442 square km), Barbados (430 square km), Saint Vincent and the Grenadines (389 square $\mathrm{km})$, Grenada (344 square $\mathrm{km}$ ) and Saint Kitts and Nevis (261 square km), are all absolutely small states.

Relatively - small states are those with a territorial surface that amounts to 10 per cent or less than any of its neighbours. This 10 per cent "rule" is based on the relative strategic advantages that may be enjoyed by the greater state in terms of strategic depth and relative vulnerability. In a conflictual dyad marked by relative asymmetry in territorial size, the smaller state is less

${ }^{31}$ CIA Factbook. 
capable of threatening the entire larger state than a situation in the inverse. The ability of a relatively small state to occupy a territory (and population) 90 per cent or more its size is nearly impossible. Contrarily, states that are $90(+)$ per cent larger than an adversary is more capable of occupying the entire small state. This is because of the relative strategic depth of the actors. Perhaps this explains the more aggressive policies of some small states vis-à-vis larger neighbours where a small state is more likely to embark on a limited aims strategy of buffer-zone building; not to conquer its larger adversary, but to occupy areas of its territory to establish a buffer so that future combat would occur on the conquered territories rather than on the national territory of the small state with its inherent vulnerabilities and lack of strategic depth. In Central and Eastern Europe, none of the members of the Warsaw Pact had a population greater than 10 per cent of the USSR, hence they were all relatively small. At the same time, in the Caribbean and Central America, all the states were less than ten per cent of the US, Brazil, and Mexico while in Latin (South) America, the majority of states are not less than 10 per cent the size of the US; though Ecuador, French Guiana, Guyana, Uruguay and Paraguay do fit the criteria for being relatively small compared to the US (and Brazil).

\section{A Summary of Small States}

It should be noted that being a small state, no matter whether absolutely or relatively small may be more vulnerable though this does not necessarily indicate weakness; small states can be powerful even if at a demographic or territorial disadvantage. ${ }^{32}$ However, in the clear majority of cases, small states retain very limited power and hence tend not to be aggressive; they tend to rely on alliances and alliances are, more often than not, restrictive. Or, to use the logic adopted by Aron and echoed by Maass, "small states have to have a defensive "mindset" and focus almost exclusively on their own security [... they are] unable to pursue an agenda vis-à-vis other states - because they lack the power to do so [...]." 33 This is confirmed with the cases of Central and Eastern

32 This is the main line of argumentation adopted by Michael Handel (1981), Weak States in the International System, New Jersey: Frank Cass Publishers.

${ }^{33}$ Maass (2009), p. 73. 
European and Caribbean and Latin American states during the Cold War. With very few exceptions - and restraints and political violence against internal actors notwithstanding - the Cold War period was one of interstate peace in the regions in question. While some may point to the manner in which the Cold War superpowers reined over the smaller states in their respective blocs, this work argues that the reason for (largely) peaceful relations between small states in the same bloc was the defensive nature of the international system at the time. Rewards for aggression were not worth the consequences of political abortion.

Yet, the point of this work was not to illustrate the capabilities of small states or to highlight the relative importance of such actors but rather to clearly note that

Small Powers are not simply weaker Great Powers [...] they must be defined in terms of something other than their relative power status $[\ldots]$ there is a psychological, as well as material, distinction between Great and Small Powers. The latter earn their title not only by being weak but by recognising the implications of that condition. ${ }^{34}$

So, small states are still states and not annexes to larger entities, they participate in international economic, diplomatic and political exchanges with others and contribute to their local and regional security environments. In this way, by defining small states according to their capabilities for dealing with domestic and international affairs, emphasis shifts to issues of security whereby the small state or small power cannot greatly affect the internal dynamics of its larger neighbours and therefore opts to focus its political energies on enhancing its own security position.

Hence, for this work, a small state

[...] recognises that it cannot obtain security primarily by use of its own capabilities, and that it must rely fundamentally on the aid of other states, institutions, processes, or developments to do so; the Small Power's belief in its

${ }^{34}$ Rothstein (1968), p. 29. 
inability to rely on its own means must also be recognised by the other states involved in international politics. ${ }^{35}$

And that a small state is

[...] defined by its limited capability to: (1) influence the security interests of, or directly threaten, a great power; and (2) defend itself against an attack by an equally motivated great power. ${ }^{36}$

These are based on the definition of small states developed above which notes that they are either absolutely or relatively small in terms of population and territorial size.

To be clear, small states are defined according to their demographic and territorial size. Their population size must not be larger than 1.5 million (absolute) or 10 per cent of any one neighbouring state (relative). At the same time, the territorial area of a small state must not exceed 5000 square kilometres (absolute) or be greater than 10 per cent than its neighbours.

Given these parameters, states that are deemed to be small also tend to have certain behavioural and political traits: risk aversion, alliance dependent and retain limited international influence in pursuit of self- and international interests. In short, small states retain limited international power based on limited internal capabilities and the means of projection. The small state recognises its own security vulnerabilities, as do others, and therefore the world is divided into allies (potential or actual security providers) and adversaries (potential or actual security diminishers); there are few international nuances. This may explain the manner in which the states of Latin America, the Caribbean and Central/Eastern Europe adjusted themselves following the demise of the USSR; most quickly realigned to Washington. There was little hesitation. Hungary, Poland and the Czech Republic had, within the first postSoviet decade, done a $180^{\circ}$ turn, joined NATO and in 2004, the EU. Then came the others, until the sweeping majority of Europe emerged as a unified political and strategic bloc, a process that had less to do with Euro-Atlantic values and

\footnotetext{
${ }^{35}$ Rothstein (1968), p. 29.

${ }^{36}$ Miriam Fendius Elman (1995), 'The Foreign Policies of Small States: Challenging Neorealism in Its Own Backyard,' British Journal of Political Science, 25:2, p. 171 (n. 1).
} 


\section{Mitchell Belfer}

more to do with the tenuous conditions of being small states seeking adequate alliance fixtures to reduce vulnerabilities. In Latin America and the Caribbean as well. The vast majority of states, and the people they contain, have polarised to the US with only Cuba, Venezuela and, recently, Brazil, attempting to resist US influence; but only half-heartedly.

\section{Small States in the Shadow of Empire}

Small states matter in international relations; they always have. Whether referring to Cuba - a fraction the size of the US and an even slimmer fraction of the former USSR - Grenada, Czechoslovakia or Hungary (etc.), it is clear that dominating small states and governing their ability to exercise control over foreign and security policies has assumed a rite of passage for the world's great and superpowers. The Cold War may have gone down in history as being a standoff between the US and the USSR, between the alliances of NATO and the Warsaw Pact, parliamentary democracy versus centrally planned communism, however, beneath the shroud of ideology and brinkmanship are the actors that enabled and denied the superpowers their international clout. The small states of the Cold War were just as important as the superpowers that claimed to represent them and their interests.

While this work was primarily based on evaluating the nature of small states in the international shatterbelt during the Cold War, its more subtle ambition was to classify the small state intellectually. Certainly, the eclipse of such actors in mainstream discussions and discourses is the natural outcome of having limited roles to play in a world governed by transnational engagements. However, the essence of the Cold War was for the superpower blocs to find ways to dominate small states either directly (occupation) or via proxy. In Latin America, the Caribbean Basin (and littoral) and throughout Central and Eastern Europe, many of the small states assumed international significance as a result. And now, decades removed from that epoch, and international scholarship is only marginally more aware of the impact small states produce in international systems based on the quest for power. This works contribution then, is to be found in how it viewed the political life of states forced to bask in the shadow of empire. 


\section{REFERENCES}

Belfer, Mitchell. 2014. Small State, Dangerous Region: A Strategic Assessment of Bahrain. Frankfurt: Peter Lang Publishing.

East, Maurice A. 1973. "Size and Foreign Policy Behaviour: A Test of Two Models." World Politics 25(4).

Edwards, Sebastian 2010. Left Behind: Latin America and the False Promise of Populism. Chicago: University of Chicago Press.

Elman, Miriam Fendius. 1995. "The Foreign Policies of Small States: Challenging Neorealism in Its Own Backyard." British Journal of Political Science 25(2).

Fowkes, Ben. 1999. The Post-Communist Era: Change and Continuity in Eastern Europe. New York: Palgrave Macmillan.

Garthoff, Raymond L. 1995. "Russian Foreign Ministry Documents on the Cuban Missile Crisis." The Cold War International History Project Bulletin 5: 58; 63-64.

Granville, Johanna C. 2004. The First Domino: International Decision Making During the Hungarian Crisis of 1956. College Station: Texas A\&M University Press.

Handel, Michael. 1981. Weak States in the International System. New Jersey: Frank Cass Publishers.

Hart, Jeffery. 1976. "Three Approaches to the Measurement of Power in International Relations." International Organisation 30(2).

Kornbluh, Peter. 2003. The Pinochet File. New York: The New Press.

Nicolson, Harold. 1961. The Congress of Vienna: A Study in Allied Unity, 18121822. New York: The Viking Press. [Quoted in Rothstein (1968).]

Opatrny, Josef. 2013. “Czechoslovak-Latin American Relations, 1945-1989: The Broader Context." Central European Journal of International and Security Studies, 7(3): 12-37.

Pelant, Matyas. 2013. "Czechoslovakia and Brazil, 1945-1989: Diplomats, Spies and Guerrilheiros." Central European Journal of International and Security Studies 7(3): 96-117.

Quester, George H. 1983. "Trouble in the Islands: Defending the Micro-States." International Security $8(2)$.

Rothstein, Robert L. 1968. Alliances and Small Powers. New York: Columbia University Press. 


\section{Mitchell Belfer}

Sawyer, Jack. 1967. "Dimensions of Nations: Size, Wealth and Politics," American Journal of Sociology 73(2).

Yalvac, Faruk. 2012. "Strategic Depth or Hegemonic Depth? A Critical Realist Analysis of Turkey's Position in the World System." International Relations 26. 


\begin{abstract}
Revisionist takes on the Cold War have entered public discourses and rendered understanding of the lead-up to, and unfolding of, the long game of brinkmanship between the US and USSR unintelligible. While this work does not seek to redress the meta-problems of current treatments of the Cold War, it does seek to examine some of the undercurrents during that period of international relations history. Specifically, this work presents a theoretical assessment of the small states that comprised the rank and file members of the Cold War blocs. The states of the Caribbean Basin, Latin America and Central and Eastern Europe are used to illustrate the theoretical underpinnings of this work. Ultimately, this work deviates from more conventional understandings of the Cold War by intellectually reflecting on the manner in which small states were treated by their bloc leaders.
\end{abstract}

\title{
KEYWORDS
}

Small States; Cold War; Latin America; Caribbean; Central Europe; Eastern Europe; Revolution. 